\title{
COVID-19 AS WAKE-UP CALL TO RECONSIDER THE MAINSTREAM FINANCIAL PRACTICES: ISLAMIC FINANCE PERSPECTIVE Khaled Nour Aldeen*
}

* Faculty of Economics, Damascus University, Syria

\begin{abstract}
This paper aims to present recommendations that can immune a conventional financial system against the global crisis, particularly the Covid-19 pandemic crisis from the lens of Islamic finance. This paper contends that Islamic finance is a relatively immune financial system comparing to the mainstream financial system by eliminating Riba and considering only asset-backed transactions as fruitful ones. This paper begins with the conceptual investigation of the literature on the principles of Islamic finance. The literature's origins include primary sources (Quraan and hadith) and secondary sources (books, journals, and online resources). This paper is only conceptual and does not aim to examine the issues or theories empirically. The article will be useful to develop hypotheses for future research, especially in Islamic finance. Islamic concepts will of interest, especially for countries that adopt the conventional financial system. This paper will also be useful in the introduction for both Islamic and conventional finance practitioners alike. This paper provides a conceptual model to substitute the dominant conventional economics. Highlights the necessary steps to reconsider the conventional financial system. Islamic finance can mitigate the impact of COVID-19 on the economies mainly because of the PLS (profit-loss sharing) system and Islamic ethics in financial transactions. The paper shows its originality in substance and makes a unique contribution to the literature on systems and ethics by emphasizing Islamic finance practices approaching an effective alternative to conventional finance.
\end{abstract}

Keywords: Islamic finance, mainstream finance, Covid-19

JEL Classification: G00, Y9

To cite this document: .Aldeen, Khaled Nour (2021). Covid-19 as Wake-Up Call to Reconsider the Mainstream Financial Practices: Islamic Finance Perspective. JDE (Journal of Developing Economies), Vol. 6 No. 1, 47-54

\section{Introduction}

Selflessness, solidarity, compassion have stood out amidst the novel coronavirus pandemic to become the values that unite humankind worldwide, regardless of religions, nations, and ethnic backgrounds. Islamic economics and finance principles have the natural ingredients to be at the forefront of setting those moral principles in place (Aldeen, Herianingrum, \& Al Agawany, 2020).

JDE (Journal of Developing Economies) p-ISSN: 2541-1012; e-ISSN: 2528-2018

DOI: $10.20473 /$ jde.v5i2.20955

Open access under a Creative Commons Attribution 4.0 International

(CC-BY) (c) (1) 
Muslim societies can trace the Muslim world's reform movement back to the middle of the nineteenth century. The search for authentic Islamic institutions has dominated Muslim societal reform movements' goals since the early twentieth century. In terms of financial institutions, a significant initial effort was to establish an Islamic development bank in Saudi Arabia in 1975, and it includes major commercial transactions. On the other hand, Mit Ghamr in Egypt in the 1960s was the first attempt at Islamic social banking (Asutay, 2013).

Islamic economics, finance, and banking are overgrowing in the contemporary world, particularly during the last few decades. Many countries contest the socioeconomics sector to enhance society's well-being - for instance, Indonesia, Malaysia, and Saudi Arabia as Muslim majority countries. Besides, Singapore and Nigeria as Muslim minority countries. Principally, the Islamic economy not limited to the material profit could be attained from the current world rather than considering both the present world "Dunia" plus the hereafter "Akhira," which is regarded as Muslims' ultimate goal (Kahf, 2014). In contrast, the conventional economy is materialistic and profit-oriented. The conventional economy is human-made. It's also the subject of being used against him or expiring for a particular time. The main reason that the Islamic economy and finance have received this high consideration during the last few decades is their potential, certainty, and quality in uplifting economic development and growth of the human being, aptitude in poverty reduction, and socioeconomics welfare. Moreover, promoting livelihood standards through special instruments so-called Waqf, Zakat, Sadaqah, and Infaq among society members (Kahf, 1999).

The mainstream economy is suffering from a lack of realism, lack of balance lack of moral screening; these are the effect of financialization (Aldeen, Ratih, \& Herianingrum, 2020). The financial contribution to the economy has been increased drastically, especially in the second half of the last century. In contrast, the manufacturing industry has been halved during the same period. Real state and manufacturing companies started to earn from financial portfolios rather than profit from manufacturing activities. A question arises if companies rely on interest to a large extent to make a profit, who will produce the traded amount of interest rate? That means someone will make a loss, and the other will make a profit. In other words, it is transferring wealth from looser to the gainers. Meaning this process does not increase the produced quantity. It again confirms the theory of the upside-down pyramid. Several layers of financial transactions sit on top of the real economy represented by a small basement (Real Gross domestic product). It all will create an unstoppable growing indebtedness for both government and corporation. It was subsequently adding an unprecedented size of investment in virtual assets.

The covid-19 outbreak has come as a wake-up call from the current virtual assets investment. Due to mandatory lockdown, the unemployment level has been increased, and most of the corporations become not able to produce. Can the investment through virtual assets and leveraging feed a community in such a case? The time to prevent the Coronavirus and the debate about right or wrong policies is now over. It requires a drastic mobilization from the entire nation. The crisis is hitting the world consecutively. Is it not time to take a core step and find a proper financial system to face these changes?

The most critical problem in the mainstream financial system is the financial sector's persistent and intensive misunderstanding by confusing its support and service function with wealth creation function. Moreover, the Assignment of an incorrect role to finance diverts resources to wealth transfer instead of creation through gambling approaches and activities. 
The world has not faced a significant war that lasted for 12-18 months, and the end of this dilemma is yet to be exact. This paper will address some steps to mobilize economies to relatively immune ones. The author discusses the backwardness of the mainstream economy and proposes some advisable procedures based on Islamic finance teachings. To the best of the author's knowledge, this has not been addressed before.

The remainder of the paper is arranged in the following chronological order. After the introduction mentioned above presents a brief review of the Islamic finance literature showing, the authorities and policymakers should consider the Islamic perspective and conclude.

\section{Literature Review}

\section{The Main Principles of Islamic Finance}

Islamic finance emerged mainly in the past forty years as movement $t$ reform economies in Muslim majority countries in the early 20th-century (Asutay, 2013). The failure of mainstream economics to achieve its purposes prompted Muslim researchers, financiers, and activists to raise Islamic finance as an alternative for the greedy conventional economics (Asutay, 2013). Hence, Islamic finance has come as a response to the consecutive economic' failures that have been recorded in history, whether it is nationalist, capitalist, or socialist. Islamic economics derives its genuine meaning from two primary sources: Quraan and Sunnah (Asutay, 2007). Islamic economics is described by Al- Makarim (1974) as a science which is deals with wealth and its relationship with a man from the perspective of carrying out justice in all forms of economic activities. The Islamic economy is the field of science that helps to achieve human welfare by allocating the distributing resources according to Maqasid Shariah) Shariah objectives (Chapra, 2000).

Islam identifies the five essentials (Al-Daruriyaat al-Khams): protection of life on the requirements; shelter of the religion and religious activities; protection of the body; human intellect with sound and harmonious mind's development, and soul through educational services; protection of widows and orphans; and protection of income; wealth and reallocation of wealth through economic activities (Alam et al., 2018). The most common and discussed aspect of the Islamic economy and banking is the prohibition of usury (Riba). The Islamic scripture (Qur'an) stresses the ban on usury in several verses (Qur'an, 3:130-131). Hence, it could conclude that Islamic economics is economic-based economics. It does not concentrate on greedily accumulating wealth; instead, it considers social responsibility mainly.

Islamic finance refers to a finance system that works according to Islamic roles (sharia), and it is governed by Islamic economics. Sharia prohibits charging any extra money for money that is borrowed. It is built on profit-loss sharing instead (Kamarulzaman \& Madun, 2013). The Islamic finance industry has achieved significant progress of having wider acceptance globally (Ayub, 2012). Islamic banking is overgrowing in the last few decades in both Muslim and non-Muslim countries. Furthermore, it has become a vital part of the global Islamic banking system (Rammal \& Zurbruegg, 2007) due to its resilience to the financial crisis and the mounting need for a non-conventional banking system sustainable development goals.

Islamic finance employs different functions compared to the conventional system. However, the Islamic one refers to a network that works according to Islamic law (Sharia'h), which mainly prohibits charging any extra money for money borrowed. It is built on profit-loss sharing, where all financial transactions must be asset-backed. Furthermore, it does not permit investments in any prohibited products, for instance, pork (Qur'an, 1:173) and alcohol as in (Qur'an, 1:219). 
The Islamic economy and finance's main dimensions are to enhance the human and social welfare, social security, debt, management, and distribution of wealth, consumption, taxation, debts, monetary policies, market exchange, and investment (Shinkafi et al., 2017). The subject matter has received and contemporary researches' attention worldwide, especially in the last few decades. Islamic finance has managed to achieve moderate growth in its assets and other structural and financial variables against the global financial crisis's backdrop. Thus, the question of the resilience of Islamic banks has become a common subject in conferences and writings in the contemporary world. In contrast, this resilience could be attributed to the religious-ethical foundation (Asutay, 2013).

\section{The Impact of COVID-19 on Economies}

The world health organization has declared the COVID-19 as a pandemic, severely disputed economic activities. The overall effect on the world at present is immeasurable. Some economists say that the repercussions of the COVID-19 could be far-reaching compared to the great depression of the 1930s when the global economy contracted by 26 percent.

The virus's outbreak has become one of the major threats to the global economy and financial markets. Meanwhile, coronavirus fears have rocked markets around the globe, which bond and stock prices yield plunging. The main problem from an economic perspective is not only the number of COVID-19 infected people but the extent of containment measures damage to economies, "said Ben May, head of global macro analysis at Oxford Economics (CNBC, 2020). Concerns about the worldwide spread of the COVID-19 have also motivated investors to bid up bond rates, leading to yields to inch lower in major economies. US treasuries, backed by the US government, are considered safe and haven investments to which investors continue to run in times of volatility and uncertainty in the market (Dyer, 2020). On the other hand, a decline in the global economy has decreased the oil demand, driving oil prices down to multi-year lows. The new approached strategy maintains that slowing the economy to a minimum is the way to save population's lives now, going as far as to complete lockdowns.

In reality, society is willing to sacrifice the lives of many tomorrows to save lives today. Soon, experts will begin to calculate the effects of the now generated economic holocaust on the population's life expectancy, the great poverty and unemployment, and stagnation (Salzberger et al., 2020). Successful in fact, research into potential disease treatment has begun in January 2020, and the development of new therapy or vaccine could take until 2021 . So the world economy is under control of enormous pressure to find a fixable mechanism for handling economic activities that prioritize health issues.

In this paper, we focus on the mainstream economy's consequentialist and criticizing its nature, which is based on greed and accumulating profit. The emphasis is placed on the importance of reconsidering the Islamic teachings to address the problem from the roots level rather than the symptomatic one, which produces social welfare and social welfare.

\section{The Solution from an Islamic Perspective}

History has recorded many attempts to reset the world economy's standards, aiming to manage a crisis. This re-standardization was meaningless because the proposed solution comes from the same point of view: the conventional one by keeping on the fake transaction mostly focused on transferring wealth from individuals to other individuals without any added value, which conflicts with Islamic finance teachings. The finance sector reoriented to its leading service to create wealth. Mainstream finance based on the fake transaction, trading - 
depts., and interest does not create wealth rather than remitting wealth from one individual to another.

It is going back to the basics: by redirecting the finance sector to make it play a supportive role in the real economy. Furthermore, re-diverting financial and human resources out of the speculation and return to actual wealth creation activities. It employs PLS ( profit and loss sharing) models rather than forcing a compound interest rate and considering money as a commodity that is totally against Islamic teachings when money is viewed as the moderator to ease the trading process rather than treat it as something productive.

Figuring out drastic changes in the financial sector can help rather than disturbs, distorts, and distracts the resources and the production activities.

The financial sector can facilitate the distribution of funds, that is, to the productive sector rather than attracting funds and other financial and human resources from the productive sector into speculation and trading in debt and imaginary contracts.

Regulation and supervision: which is crucial to uplift the current situation, taking into account that the new rule will not set a new standard for internet current and debt securitization. But, it should consider the real economic transaction which can add to a nation's wealth.

Asset-backed transactions mean that all financial transactions should be asset-based rather than bogus transactions that focus on the transfer of wealth between investors.

Morally-based transactions: all the assets must be of benefit to society and the environment.

By ignoring the practices mentioned above and not taking the necessary initiatives, a devastating revolt of the poor and needy against a system burdened with repetitive crises if immediate drastic changes have not been taken.

\section{Islamic Finance Instruments:}

Islamic finance can be part of the COVID-19 response through a range of financing instruments well-suited for each stage:

Table 1: Islamic Finance Instruments and Their Role in the Pandemic

\begin{tabular}{c|l}
$\begin{array}{c}\text { Emergency support in the } \\
\text { short term }\end{array}$ & $\begin{array}{l}\text {-Zakat, Infaq, Sadaqah can be used to support } \\
\text { health care, food, and other immediate needs. }\end{array}$ \\
\hline $\begin{array}{c}\text { Response and recovery in } \\
\text { the medium term }\end{array}$ & $\begin{array}{l}\text {-The financing of equipment, vehicles, and other } \\
\text { livelihood and trade finance sources are critical } \\
\text { mechanisms by which Islamic banks and financial } \\
\text { institutions can support recovery. }\end{array}$ \\
\hline $\begin{array}{c}\text { Long-term recovery and } \\
\text { resilience }\end{array}$ & $\begin{array}{l}\text {-Sukuk (bond equivalents) can be an important } \\
\text { source of long-term capital. }\end{array}$ \\
-Waqf endowments can be important contribu- \\
tors to long-term resilience.
\end{tabular}

Source: Author's Illustration 
There are several instruments in Islamic finance. Each one has its specific criteria-table 1. Elaborate on the tools and where they should be employed. For instance, they could use the Zakats and Infaq for emergency issues such as buying medicines or covering medical expenses during the pandemic. On the other hand, Waqf, including the cash Waqf and Sukuk, could be used for long-term issues. For instance, they are financing a new hospital or fixed assets in a hospital as well.

Islamic finance institutions such as Islamic banks and Islamic insurance companies play a crucial role since the fund provided by sustainable sources (Waqf and Sukuk), and sort-term sources might not be sufficient in some cases. Therefore, Islamic finance institutions should consider the pandemic situation plus provided and relevant products to be used during the pandemic. The availability of such products concerning the Covid-19 outbreak will enhance the Islamic banking credibility as an immune system against the crisis.

\section{Employing Islamic Finance Ethical Teachings in the Mainstream Finance System}

The recommendation based on Islamic values to the mainstream economy: decision and policymakers. Why we need them? And the most important question is, what is the benefit added through these conventional financial products?

\begin{tabular}{|c|c|}
\hline $\begin{array}{l}\text { The gradual elimination } \\
\text { of zero-sum and other }\end{array}$ & $\begin{array}{l}\text { Internet currency forms forex trades trading indices betting on currency } \\
\text { prices short trades. }\end{array}$ \\
\hline $\begin{array}{l}\text { The gradual elimination } \\
\text { of credit and insurance } \\
\text { derivatives and all }\end{array}$ & $\begin{array}{l}\text { Stop options trading. } \\
\text { Limit options to hedging only buy or sell provided with conditions of } \\
\text { having a position. } \\
\text { Disallow securitization of credit derivatives and credit insurance } \\
\text { contracts. }\end{array}$ \\
\hline & Disallow day trading in all markets. \\
\hline The gradual elimination & Eliminate market makers and eliminate organized markets. \\
\hline $\begin{array}{l}\text { of speculative patterns } \\
\text { of behavior }\end{array}$ & $\begin{array}{l}\text { Reduce the market accessibility and lengthen the trade process to make } \\
\text { it only for those who want to involve in genuine trade transactions (buy } \\
\text { and sell contracts). }\end{array}$ \\
\hline $\begin{array}{l}\text { Genuine organized } \\
\text { market }\end{array}$ & $\begin{array}{l}\text { Add conditions of genuineness to equity trading. } \\
\text { Restrict commodity futures to thedging real market positions only. } \\
\text { Restrict currency futures to hedging real market positions and add } \\
\text { conditions to defining who can trade currencies. }\end{array}$ \\
\hline & Remove interbank debit transactions. \\
\hline $\begin{array}{l}\text { Must connect all the } \\
\text { finance transitions to a } \\
\text { real }\end{array}$ & $\begin{array}{l}\text { Remove securitization of debts along with their domino effect. } \\
\text { Intrinsically and functionally link credit to the need of the real market. } \\
\text { Take away loans to the arena of personal relations by particular no- } \\
\text { banking institutions. }\end{array}$ \\
\hline $\begin{array}{l}\text { Create a financial } \\
\text { industry ombudsman } \\
\text { (Muhatasib) }\end{array}$ & $\begin{array}{l}\text { With a say over products and transactions. } \\
\text { It should be in all markets to give an early warning. } \\
\text { It introduces a moral element to contain greed. }\end{array}$ \\
\hline $\begin{array}{l}\text { Create a stand-by } \\
\text { public-sector financial } \\
\text { institution }\end{array}$ & $\begin{array}{l}\text { A financial institution that can provide direct finance to the real market } \\
\text { when necessary. }\end{array}$ \\
\hline
\end{tabular}

Figure 1: Islamic Finance Instruments and Their Role in the Pandemic

Source: Author's Illustration

Figure 1. It mainly focuses on three aspects, namely, 1) speculative transactions, asset-backed financial transactions, and 3) regulator role. Authorities should direct and control the investment process, assign investments to priority sectors, and refrain from financing unduly or speculative ventures. They play many vital roles, namely, an educator for the society, a 
new product innovator, and a mentor. Hence, ensuring the gradual elimination of all zero-sum transactions.

\section{The Role of Central Banks}

Modern economies rely heavily on the central bank to stabilize and expand because of their stability and growth to their various significant roles, including development and traditional roles. A central bank may fail to achieve its broad objectives if it cannot use conventional interest-based instruments to perform its functions. Nevertheless, an economic system that is envisaged to be governed in the light of Islamic principles cannot use these instruments; consequently, central banks in Muslim countries, which operate an Islamic financial system, must adopt a completely different model.

Central banks have a major role too since it is the heart of an economy. Hence, they play a vital role in advising and directing all the financial institutions in an economy. The central banks should highly consider such a sensitive initiative. The following are the main points that should be highlighted by any central bank willing to Islamize an economy: First and foremost, define Islamic finance contracts that put them all in the correct perspective and standardized their practices. Moreover, Increase inclusiveness and deepen the penetration of banking in the economy. It was eliminating the pure-debt transactions in all banks, Islamic and conventional, by trying finance to goods \assets as objectives of it. Activate depositors' role to be participatory in the simple operations (profit and loss of the bank, not as creditors of the bank.

Reformulate and strengthen the Shariah governance, issue Shariah governance guidelines, and compliance framework. Central banks have to Issue regulation for Sukuk and introduce several unified, sovereign, and corporate Sukuk to enhance liquidity management.

Eliminate pure-cash transactions, no debt circulation, and trade and Standardize profit distribution to investment account holders on economic fairgrounds. Improve corporate governance to recognize the rights of IAHs vis-à-vis shareholders.

Standardize accounting disclosure and treatment of IA in the balance sheet. Furthermore, standardize the processes of Islamic banking, AAOIFI, and IFSB. Create a robust market infrastructure for the internal capital market. Avoided virtual assets and virtual contracts, including derivatives which include futures, options, index trading, and internet forex trading. Moreover, eliminating speculation in all markets.

Provide adequate consumer protection, for instance, introducing the applications of ijarah ending with ownership). Create a robust market infrastructure for the internal capital market. Avoided virtual assets and virtual contracts, including derivatives which include futures, options, index trading, and internet forex trading.

\section{Conclusion}

The purpose of this article is to highlight some procedures that might mitigate the financial repercussions attached to the unprecedented events considering the COVID-19 breakout. We stressed that Islamic finance is a proper solution to reduce risk in the financial crisis case mainly because it is attached to genuine assets. It considers the ethical teachings of Islam, which can help to address any gaps in mainstream finance. What is more, we have highlighted the role of central banks in this regard. The information discussed in the study is significant since there is a scarce of studies that address the COVID-19 economic repercussions from the Islamic finance point of view. Same with any research, this paper has some 
limitations. This paper only provided a piece of conceptual information. Further studies might address the practicability of the proposed initiative through interviewing authorities, moreover, addressing the main reason beyond not implementing Islamic teaching from the early beginning of the crisis since the mainstream teaching failed to address the human needs and the consecutive situation.

\section{References}

Al- Makarim, Z. A. (1974). Ilm al 'Adl al lqtisadi (The Science of Just Economics. Dar al Turath.

Alam, M. M., Shahriar, S. M., Said, J., \& Monzur-E-Elahi, M. (2018). Waqf as a tool for rendering social welfare services in the social entrepreneurship context. Global Journal Al-Thaqafah. https://doi.org/10.7187/gjatsi2018-06

Aldeen, K. N., Herianingrum, S., \& Al Agawany, Z. M. W. (2020). Islamic vs. Conventional Banks in Syria: Analysis on Financial Performances. Shirkah: Journal of Economics and Business. https://doi.org/10.22515/shirkah.v5i1.291

Aldeen, K. N., Ratih, I. S., \& Herianingrum, S. (2020). Contemporary Issues on Cash Waqf: A Thematic Literature Review. International Journal of Islamic Economics and Finance (IJIEF). https://doi.org/10.18196/ijief.3236

Asutay, M. (2013). Islamic moral economy as the foundation of Islamic finance. In Islamic Finance in Europe: Towards a Plural Financial System. https://doi. org/10.4337/9781781002513.00014

Asutay, M. (2007). A Political Economy Approach to Islamic Economics: Systemic Understanding for an Alternative Economic System. Kyoto Bulletin of Islamic Area Studies. https:// doi.org/10.14989/70894

Ayub, M. (2012). Understanding Islamic Finance. In Understanding Islamic Finance. https:// doi.org/10.1002/9781119209096

Chapra, M. U. (2000). Why has Islam Prohibited Interest: Rationale behind the Prohibition of Interest. Review of Islamic Economics.

CNBC. (2020). 6 charts show the coronavirus impact on the global economy and markets so far. https://www.cnbc.com/2020/03/12/coronavirus-impact-on-global-economy-financialmarkets-in-6-charts.html

Dyer, O. (2020). Covid-19: Trump declares intention to "re-open economy" within weeks against experts' advice. BMJ (Clinical Research Ed.). https://doi.org/10.1136/bmj.m1217

Kahf, M. (1999). Financing the development of "Awqaf" property. The American Journal of Islamic Social Sciences. https://doi.org/10.35632/ajis.v16i4.2099

Kahf, Monzer. (2014). Budget deficit and instruments of public borrowing in the Islamic system. In Handbook on Islam and Economic Life. https://doi.org/10.4337/9781783479825.00038

Kamarulzaman, Y., \& Madun, A. (2013). Marketing Islamic banking products: Malaysian perspective. Business Strategy Series. https://doi.org/10.1108/17515631311325114

Rammal, H. G., \& Zurbruegg, R. (2007). Awareness of Islamic banking products among Muslims: The case of Australia. Journal of Financial Services Marketing. https://doi.org/10.1057/ palgrave.fsm. 4760060

Salzberger, B., Glück, T., \& Ehrenstein, B. (2020). Successful containment of COVID-19: the WHO-Report on the COVID-19 outbreak in China. In Infection. https://doi.org/10.1007/ s15010-020-01409-4

Shinkafi, A. A., Ali, N. A., \& Choudhury, M. (2017). Contemporary Islamic economic studies on Maqasid Shari'ah: a systematic literature review. Humanomics. https://doi. org/10.1108/H-03-2017-0041 